\title{
Senneh Gelim and Gelim Weavers: An Interdisciplinary Study of the Contem- porary Production of a Traditional Kurdish Carpet in Iranian Kurdistan
}

Reyhane Mirabootalebi

Preservation Studies, Art Conservation Department, University of Delaware, Newark, Delaware, USA

reyhanem@,udel.edu

Reyhane Mirabootalebi is an objects and textiles conservator. She has a Ph.D. in Preservation Studies from the University of Delaware, USA (2021) and an M.A. in Cultural Materials Conservation from the University of Melbourne Australia (2011). Her doctoral research focused on the Kurdish textile traditions of Iran and Iraq. 


\title{
Senneh Gelim and Gelim Weavers: An Interdisciplinary Study of the Contem- porary Production of a Traditional Kurdish Carpet in Iranian Kurdistan
}

\begin{abstract}
This article is an interdisciplinary study of senneh gelim and its female gelim weavers. Senneh gelim is a significant living (flatwoven) carpet tradition of the Iranian Kurds. Based on primary data collected by the author during fieldwork in Iranian Kurdistan (2018-2019) and the existing ethnographic, social historical, and art historical studies, this research traces the senneh gelim developmental trajectory from the late eighteenth century up to the present. The analysis of social processes shows that senneh weaving reflects weavers' experience of oppression and exploitation resulting from their social identity: class, gender, and ethnicity. This work demonstrates that this inherent inequality within the production systems and external factors such as the region's geopolitics undermines senneh gelim's potential to be a sustainable means of livelihood for women weavers, thus threatening the development and future preservation of this significant Kurdish and Iranian textile heritage.
\end{abstract}

Keywords: senneh gelim/kilim, sojaee, Kurdish textile craft heritage, Near Eastern traditional textiles, women carpet weavers

\section{Introduction}

Kurdish textile traditions have roots in ancient craft practices in the Near East and represent an integral part of specific communities' cultural and artistic heritage. However, the literature on Kurdish textiles is scarce and limited. Studies of Iranian carpets were initiated in the West in the second half of the $19^{\text {th }}$ century and centered almost exclusively on luxurious knotted piled rugs. By contrast, flatweaves were regarded as village-made and tribal fabrics, thus dismissed as inferior in aesthetic value and craftsmanship and generally omitted from the scholarly works of that era. ${ }^{1}$ It was not until the 1960 s and 1970 s that, because of the rising popularity of flatweaves as exotic Oriental tribal textiles, they appeared in private and public collections, and subsequently, were subject to scholarly attention. ${ }^{2}$ Among the emerging literature, a few scholars focused on 
flatweaves from Kurdistan, including Anthony Landreau (1973), Cathryn Cooter (1981), William Eagleton (1983), Anahid Akashe (1986), Wilfred Stanzers (1993), Parviz Tanavoli (2002), and James D. Burns (2002). ${ }^{3}$ Although invaluable sources of visual documentation and technical knowledge, these studies are, however, predominantly collection-based, focusing on stylistic and iconographic analyses of the textile objects with inadequate attention given to the social contexts of production or to the weavers' roles and identities. Still lacking is a comprehensive study of craft objects as representative of living traditions and as rich repositories of social and cultural knowledge.

C.L. Costin (1998) argues, 'without attention to artisan identity our reconstructions of production systems and explanations of their form and dynamic are destined to be unidimensional and unidirectional, lacking in key elements of social process and social behavior. ${ }^{4}$ As such, this article, based upon fieldwork conducted in Iranian Kurdistan from July 2018 to September 2019 with nearly eighty individuals currently engaged in the production and trade of traditional Kurdish textiles, explores in detail both the formal qualities of textiles and their social, economic, and gendered role as vital elements for understanding the craft tradition's development and continuation. ${ }^{5}$

\section{Background: senneh gelim, a noble craft with humble origins?}

Senne gelim or sojaee, as referred to locally, is a significant living Kurdish textile heritage that appears to have formed in the eighteenth century in the city of Sanandaj at the conjunction of the enormous Safavid (1501-1722) urban carpet industries and centuries-old local Kurdish tribal and rural weaving traditions. Little is known about the origin of this highly prized urban flatweave and how it developed to be different from other flatweave types extensively made by predominantly rural and nomadic Kurdish groups in the region (Figures 1, Figure 2). 


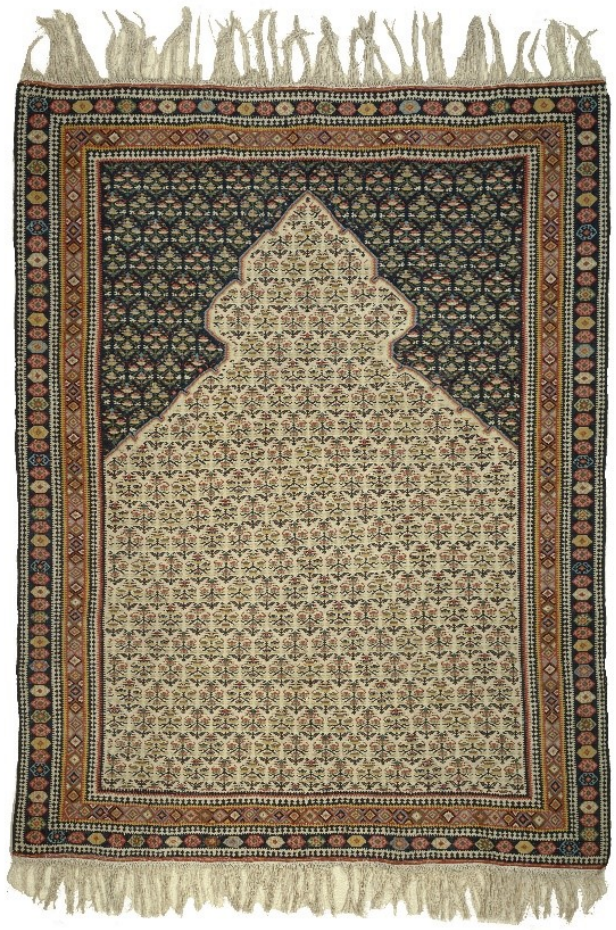

Figure 1. A senneh gelim, dating from the mid-to-late nineteenth century, with a mehrabi layout and floral design pattern. A. Levi (1993) suggested the floral patterns were derived from the famous Safavid's Garden pile carpets. Courtesy of the George Washington University Textile Museum, gift of Arthur D. Jenkins (object number: 1979.35.1).

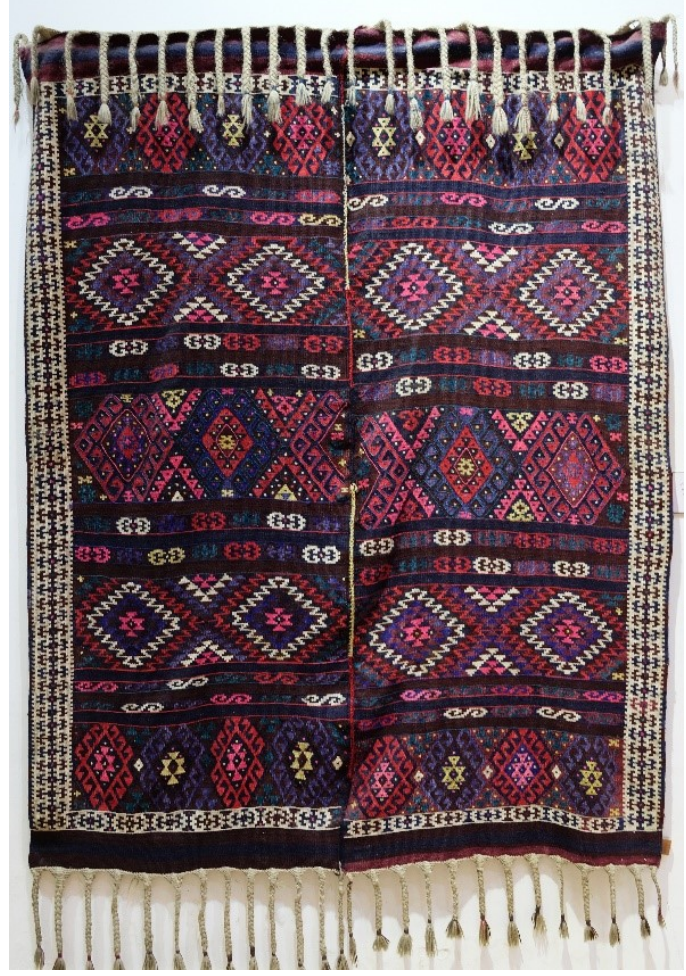

Figure 2. An example of a rural flatwoven carpet locally known as barr, comprised of two pieces sewn together, made by Herroti tribe, Iraqi Kurdistan, dates to the mid-twentieth century. Courtesy of the Kurdish Textile Museum, Erbil. Photographed by the author, October 2018.

However, based on stylistic and iconographic analyses, the (scant) existing studies on historical and early examples have suggested that senneh gelim was developed in the eighteenth century as an urban weaving tradition. ${ }^{6}$ The masterful execution of slit-tapestry technique, intricate designs, and top-quality local and imported materials (wool, silk, and cotton) evident in the early pieces rank senneh gelims with the fine Safavid silk gelims developed probably during the reign of Shah Abbas I (1588-1629) (Figure 3). ${ }^{7}$ These fine Safavid silk gelims served as noble diplomatic and religious devotees' gifts (as wall hangings and tomb covers) to the Shi'i shrines in Karbala and Najaf. ${ }^{8}$ Further, Tabriz, the Safavids' first political capital, was a significant centre of textile production and trade and probably the birthplace of Safavid silk gelims. ${ }^{9}$ Tabriz's geo- 
graphical proximity to Sanandaj, Tanavoli (2002) suggests, might have triggered the development of Sanandaj's senneh gelim tradition. However, as he indicates, unlike Safavid textiles made in urban and royal workshops presumably by master craftsmen, senneh gelim was a product of domestic workshops and made by women as a commission-based or commercial item, a significant aspect of the tradition that still stands.

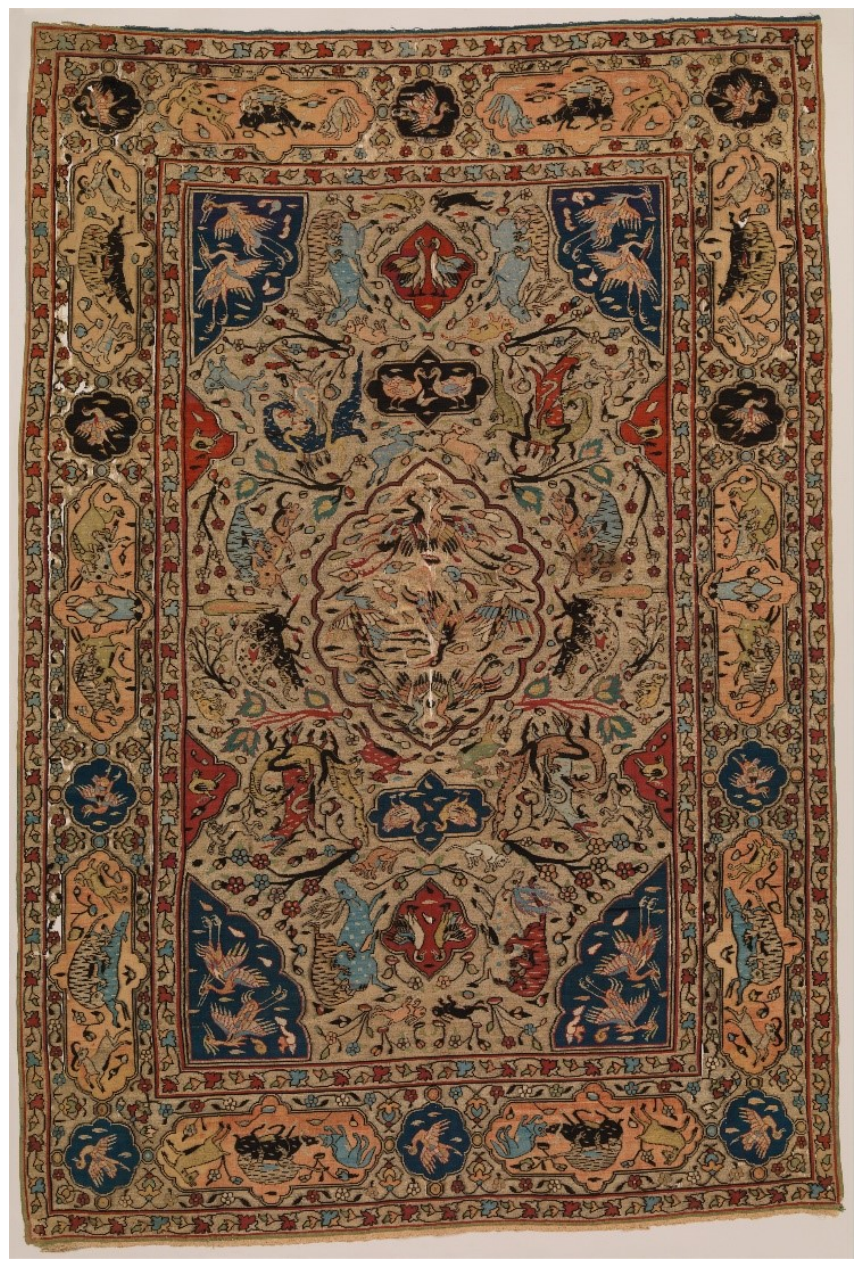

Figure 3. A Safavid silk tapestry dates from the late sixteenth to early seventeenth century, probably made in Kashan, Iran. Courtesy of the Metropolitan Museum of Arts, bequest of Isaac D. Fletcher, 1943 (Accession Number: 43.84). 
It has also been suggested that the senneh tradition was developed and thrived under the auspices of the Ardalans, a princely Kurdish dynasty (1169-1867) that ruled over a significant part of Kurdish regions under the central power for several centuries..$^{10}$ The Ardalans benefited from trade routes in the southern part of the so-called Silk Road that passed through Kermanshah by controlling the commerce of foodstuffs, fibre, and fabric. They established the city of Sanandaj, or Senneh/Senne, as their seat in 1636, one of the earliest and most important urban centres for the Kurds until to date. Being influenced by the arts of the Safavid and Qajar courts, the Ardalans followed in their footsteps, becoming patrons of arts and architecture in their regions. In all likelihood, the development of senneh gelim as a prestigious textile for Kurdish nobilities and a refined urban commodity for trade could have occurred at the instigation of local Kurdish khans and nobles in the eighteenth century.

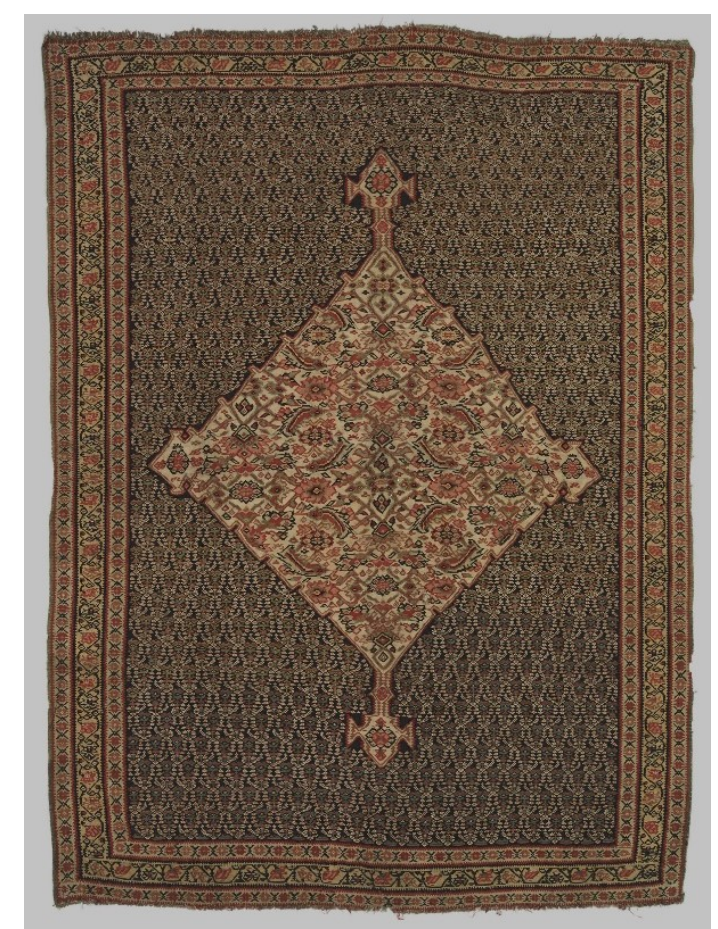

Figure 4. Senneh, dates to the nineteenth century. Courtesy of the Victoria and Albert Museum (accession number: 321-1896). 
Senneh gelim continued to flourish under the Qajars (1789-1925), as suggested by exquisite pieces dating from the nineteenth to early twentieth centuries (Figure 4). Notably, the late-nineteenth to early twentieth century marked a significant period in the history of handmade carpets in Iranian territories. By the 1880s, American and European rug merchants (e.g., Ziegler and Company) began to identify traditional weaving centres and establish commercial rug workshops across the country. ${ }^{11}$ This marked the decline of the old production system of urban pile handmade carpet workshops - that is, those which were patronage-based and (limited) commercial — and the beginning of modern capitalist mass production. By the end of the nineteenth century, Persian pile carpet was a major commercial industry centred in urban and rural workshops and factories. The commercial pile carpet workshops emerged in Kurdistan as early as the $1880 \mathrm{~s}^{12}$ while senneh gelim production appeared to have evaded the wave of modern capitalist commercialization of the Iranian carpet industry at the time, as flatwoven carpets were not as highly regarded as pile carpets. Yet, the existence of antique senneh gelim pieces dating to this period suggests that unlike many indigenous handmade textiles which disappeared as a consequence of industrial production, senneh weaving was maintained as a cottage industry until its revival around the 1960s and 1970s. ${ }^{13}$

The senneh gelim market most likely began to prosper in the 1970s in response to a demand for ethnic and tribal carpets emerging in the West. ${ }^{14}$ The (second) Pahlavi government (1941-1979) appears to have formulated some policies or programs around this time to help revive the traditional crafts by reinvigorating them as a sector of the economy. ${ }^{15}$ Rapid changes to social, political, and cultural landscapes occurred in this period in Iran due to the state-sponsored modernization policies led to the emergence of public nostalgia for old traditions and cultural materials; hence a market developed for traditional artifacts such as senne gelim, which were rebranded as ethnic, traditional crafts to appeal to modern-day consumers. According to senior weavers in Sanandaj, concentrated/communal senneh gelim workshops were active training and production centres in Sanandaj in the late 1970s and the 1980s, set up in many neighbourhoods across the city and attracting women and girls from urban working-class families with a prospect 
for a domestic career and an independent and relatively reasonable income. These institutes continued to be active for some years after the Iranian Revolution of 1979, but gradually disappeared. With the decline of the short-lived communal workshops, weaving senneh gelim once again returned to its former mode of production, that is, primarily in domestic settings.

Despite going through cycles of rise and fall over three centuries, today, senneh gelim continues as a cottage industry and commercial craft of Kurdish women in Sanandaj and has appeared as an income-generating source in many remote regions in Iranian Kurdistan province (Figure 5, Figure 6). While in the past, it was common for a weaver to begin commercial carpet weaving often as early as age seven or eight, today, however, carpet weaving is mainly taken up as a means of income by adult women who have no access to jobs outside the domestic sphere. As will be seen, many women make senneh gelim in the home alongside and in addition to attending to family members, bearing and rearing children, and household chores. Senneh weavers in the urban milieu generally do not perform any other economic activity outside their households, while among village weavers and many recent rural immigrants in Sanandaj whose families still hold (or have leased) farmlands in their villages, the production of senneh gelim is complementary to agricultural and animal husbandry activities. There, because women make up a large part of the agricultural labour force, their chief occupation from mid-spring to the fall is farming, and the weaving season peaks during colder seasons when farm-related activities are less intense.

Like in the pre-industrial production era, the carpet bazaar remains at the centre of all economic and social activities pertaining to handmade carpet production, such as the trade of raw materials and finished products in internal and export markets. Today it functions through vast and interrelated networks of local, regional, and national agents comprising private loom owners, carpet shopkeepers in the marketplaces, and petty-to-large dealers and merchants scattered throughout regional towns and larger cities. However, as will be seen, while women play the crucial role in weaving the carpets, for the most part, the role of weavers ends when their gelims are 
cut off the looms. Before exploring the contemporary realities of weavers and senneh gelim production, I turn to an examination of the carpets themselves. Examining senneh gelim patterns to reflect their construction and aesthetics can shed light on the developmental trajectory and provide insight into how contemporary rugs fit into a longer history.

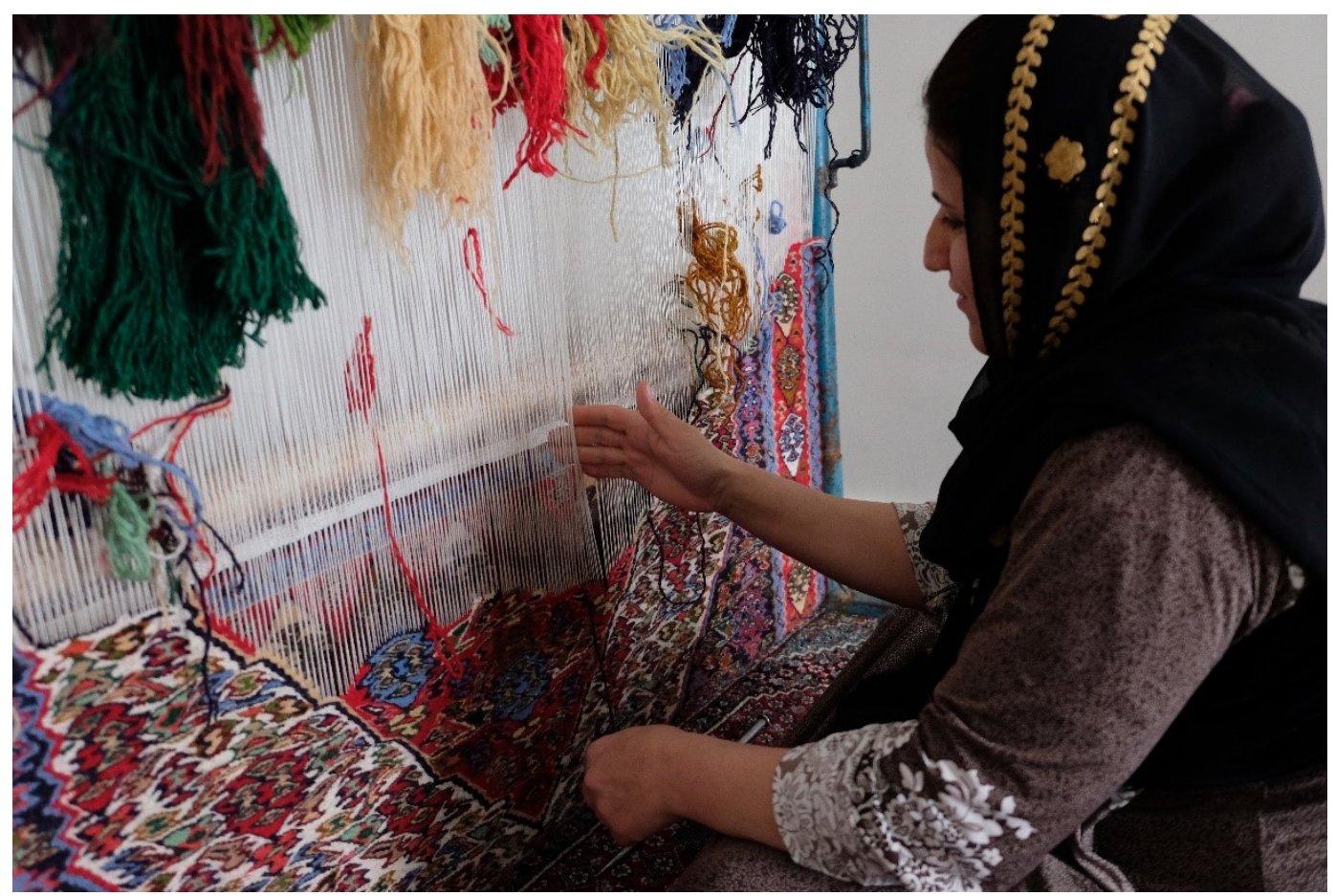

Figure 5. Mahin is an independent senneh weaver from the village of Buridar, Iranian Kurdistan. Photographed by the author. January 2019. 


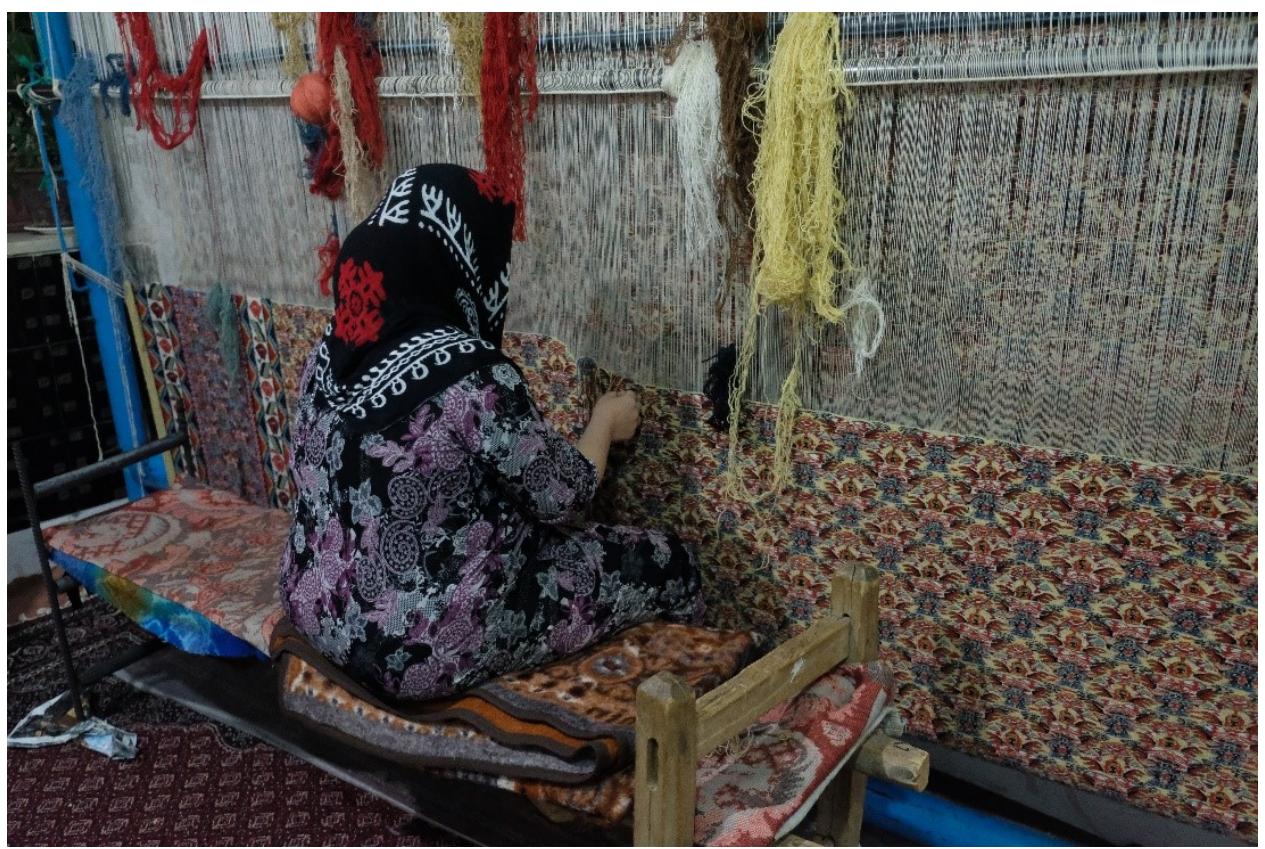

Figure 6. Golchin a senneh gelim artisan, a dependent urban weaver works at home in Naysar, Sanandaj. Photographed by the author. December 2018.

\section{Senneh gelim: change and continuity}

The weaving method of senneh gelims requires some explanation as it has a direct bearing on the creation of patterns and design possibilities. Senneh gelim is a slit-tapestry using an eccentric weft-faced technique and is woven on a vertical loom. Since the weft yarns carry the pattern, the weave must be weft-faced; that is, the weft yarns cover the warp yarns and must be so tightly packed together during weaving that they completely cover the warp yarns. Also, two color areas meet vertically with each weft yarn turning around the last individual warp yarn at the edge of its color area, thus creating a vertical opening between the two colors called a slit. Slit has an enormous impact on gelim designs - the ordering of the color areas to avoid excessively long slits results in the characteristic design shapes such as diamonds, triangles, triangles, and lozenges. Using both fine and thin woolen yarns enables artisans to weave highly complex and curvilinear design motifs and forms.

In regard to raw materials, wool (sheep's wool) has always been a predominant material in the production of senneh gelim and is used for both the foundation/warp (chelleh) and weft (pood). In contemporary Kurdistan, cotton is commonly used for the foundation/warp for low-to- 
average-quality senneh gelims. For gelims intended for high-end markets, mainly for export, wool is the preferred material for warp. Until several decades ago, wool of the highest quality in the Kurdish region was sourced locally as an abundant byproduct of animal husbandry. However, the local handspun wool processed by women has long been replaced by industrially processed wool coming from factories outside Kurdistan, mainly Tabriz, in various types and qualities.

Returning to weaving techniques, in Iranian weaving terminology, the method of weaving senneh is described as a hefzi-baaf and zehni-baaf, meaning the weaver makes senneh from memory (hefzi) and imagination (zehni). This implies that design motifs are created by drawing on a range of learned patterns in contrast to the pile carpet weaving technique in which the weaver relies on a visual representation of pattern or naghshe as a guide to create the designs. The memorization of patterns is part of the learning process, acquired through endless repetition and prolonged practice. Still, traditional senneh patterns were borrowed largely from pile carpets in design composition and motifs. They display one or a combination of several variations of prominent compositions, namely kolah-farang (medallion[s] with/without corner pieces), kheshti/ghāb-ghābi (divided into squares/compartments), vāgireh (simple layout), moharamāt (stripes), and mehārbi (prayer arch). ${ }^{16}$ These compositions provide a layout within which the design motifs are repeated.

The repertoire of senneh patterns comprises a range of traditional designs executed in many different stylistic variations, colours, and combinations. The most prominent traditional senneh patterns are the Herati (also called mäsi-dar-ham in Kurdi referring to mähi-dar-ham or the fish design), boteh, gol-vakili, gol-o-goldān, gol-mohammadi, gol-mirzā-ali, kochke-kolo or rig-e-rokhāne also called fath-ali-shāhi, qabqāzi or qafqāzi (meaning Caucasian), qol-e-chāi, and gol-e-chini. ${ }^{17}$ Most prominent traditional patterns seem to have been developed prior to the early twentieth century and were mainly derived from non-Kurdish sources, including the Safavid garden piles and other important and fashionable Iranian and imported European textile designs during the Qajar period (Figure 1, Figure 7). ${ }^{18}$ 


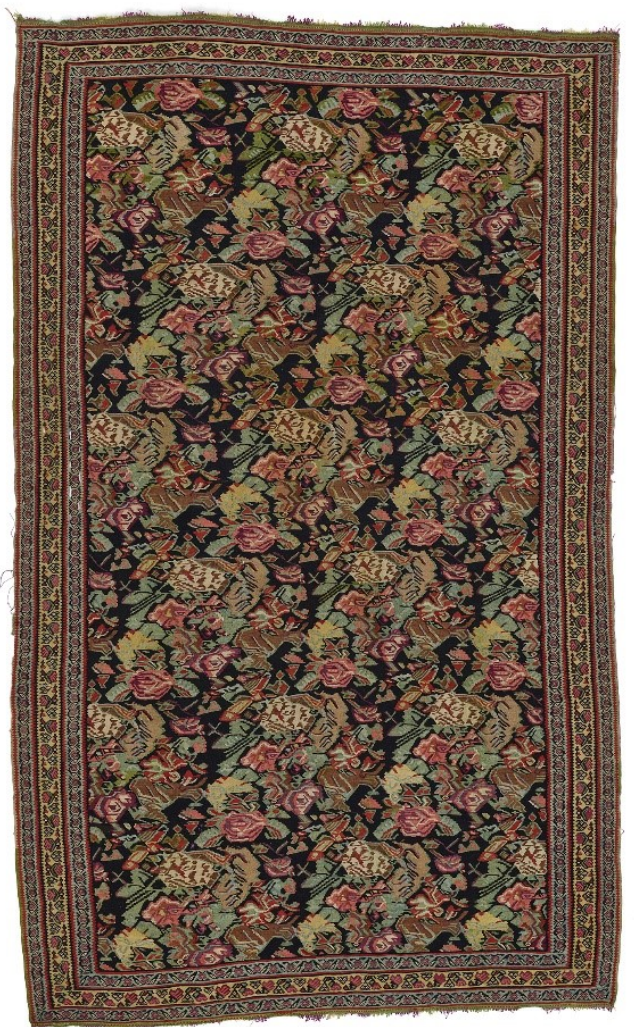

Figure 7. A senneh gelim vagireh layout and a freestyle floral pattern locally known as kochke-kolo or rig-e-rokhane, or Fath-Ali-shahi by some non-local experts. The pattern is inspired by imported French carpets designs. Courtesy of the George Washington University Textile Museum, gift of Arthur D. Jenkins (object number: 1989.10.56)

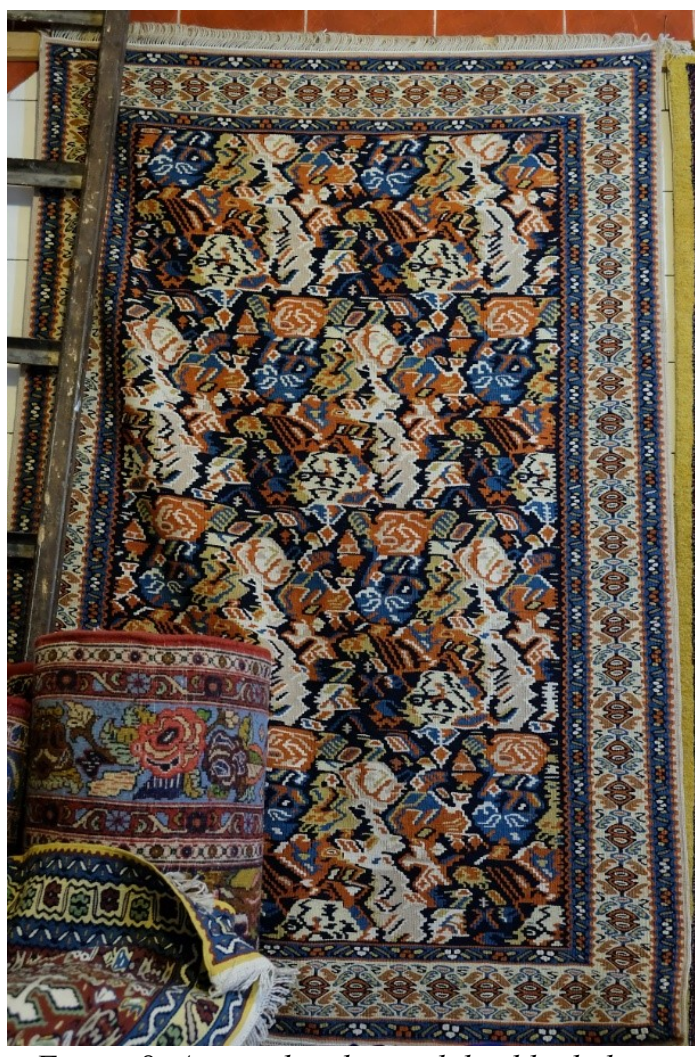

Figure 8. A senneh gelim with kochke-kolo or rig-e-rokhane (compare with Fig. 8), on sale at the Sanandaj carpet bazaar. Photographed by the author. September 2019.

However, other old patterns, underrepresented in collections and absent in the literature, seem to have deep roots in local history. Senneh gelims with these patterns continue to be produced in Sanandaj, though rarely. An example is naghshe-Mosā or the Moses design, as specified by the name and characteristic motifs such as snakeheads, indicate Judaism's ancient history in Iran's Kurdish regions (Figure 9). Today, a neighbourhood in the older quarter of Sanandaj still referred to as the Jewish neighbourhood among the residents was once a vibrant Kalimi or Jewish community in the city. Notably, both the Christian and Jewish Kurds were specialized skilled workers and craftspeople, particularly in textiles and trade and related crafts. ${ }^{19}$ For instance, the most well-known dye masters in Sanandaj were Jewish, and today their names are 
still remembered by senior traders in the Sanandaj bazaar despite the fact that populations of Jews and Christians decreased dramatically due to extensive migration in the 1960s and 1970s.

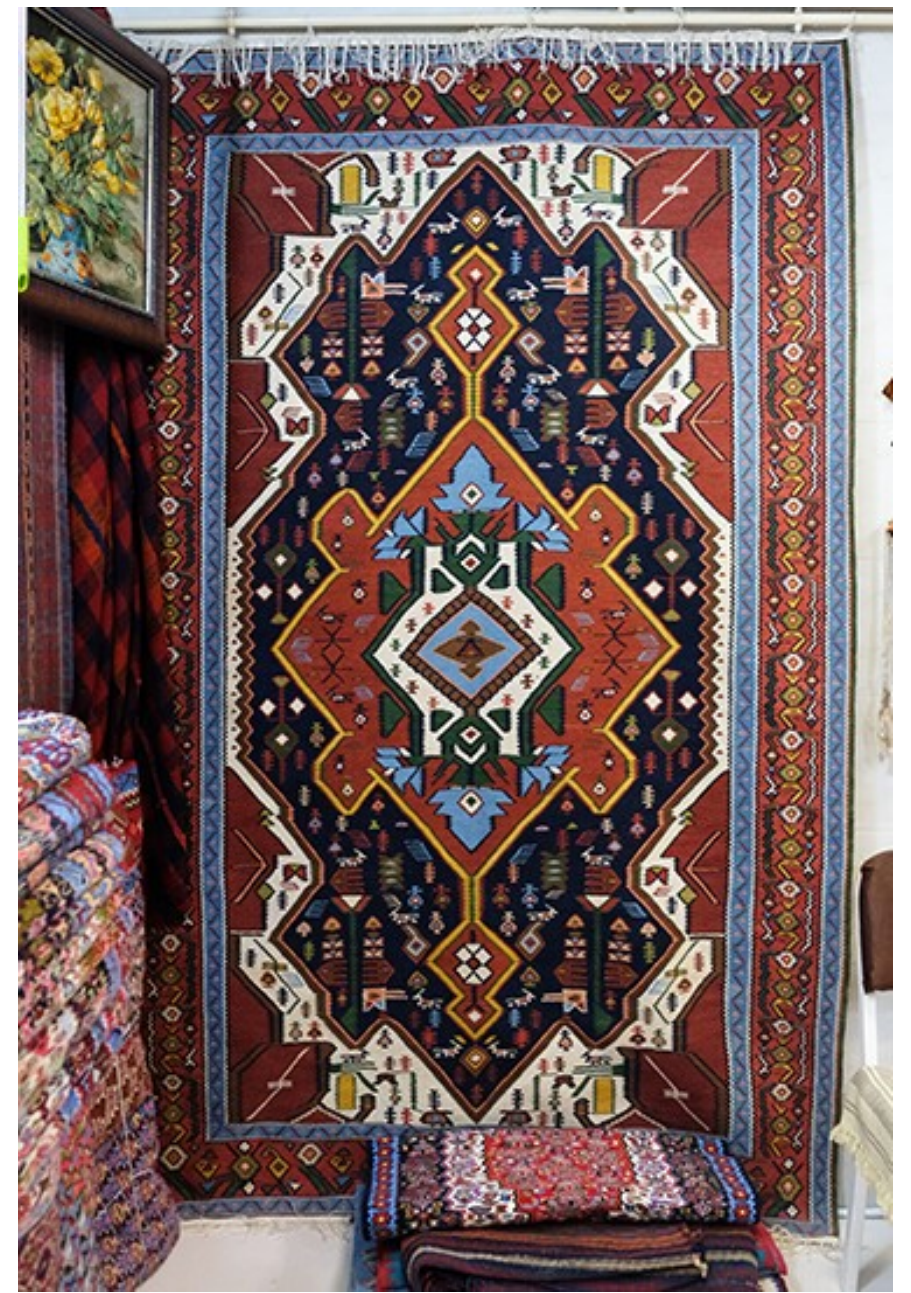

Figure 9. A senneh gelim with the naghsh-e-yahood or the Jewish pattern, on display for sale in the Sanandaj bazaar. Photographed by the author. July 2019. 
The observation of contemporary senneh gelims shows that modern patterns follow recognizable and traditional designs and have remained faithful to the famous classic form (compare Figure 7 and Figure 8) with innovations mostly limited instead to small variations within the familiar (and perhaps more marketable) design elements; thus new patterns rarely emerge (Figure 10). Of well-known senneh patterns, the Herati or the fish design remains widely produced across all contemporary rural and urban production centres. One of the most difficult patterns to weave with the slit-tapestry technique because of busy and elaborate design elements, this popular pattern is executed in many different stylistic variations, colours, and combinations so that, in some areas, regional styles have formed. The Herati design dominates town and village looms to the extent that other senneh patterns are remembered only by some senior weavers, and likely it will not be long before they completely fade away from weavers' collective memories. Other patterns, such as kochke-kolo (otherwise known as rig-e-rokhane) and naghshe-Mosā, are still produced mainly in urban workshops, but to a much lesser extent.

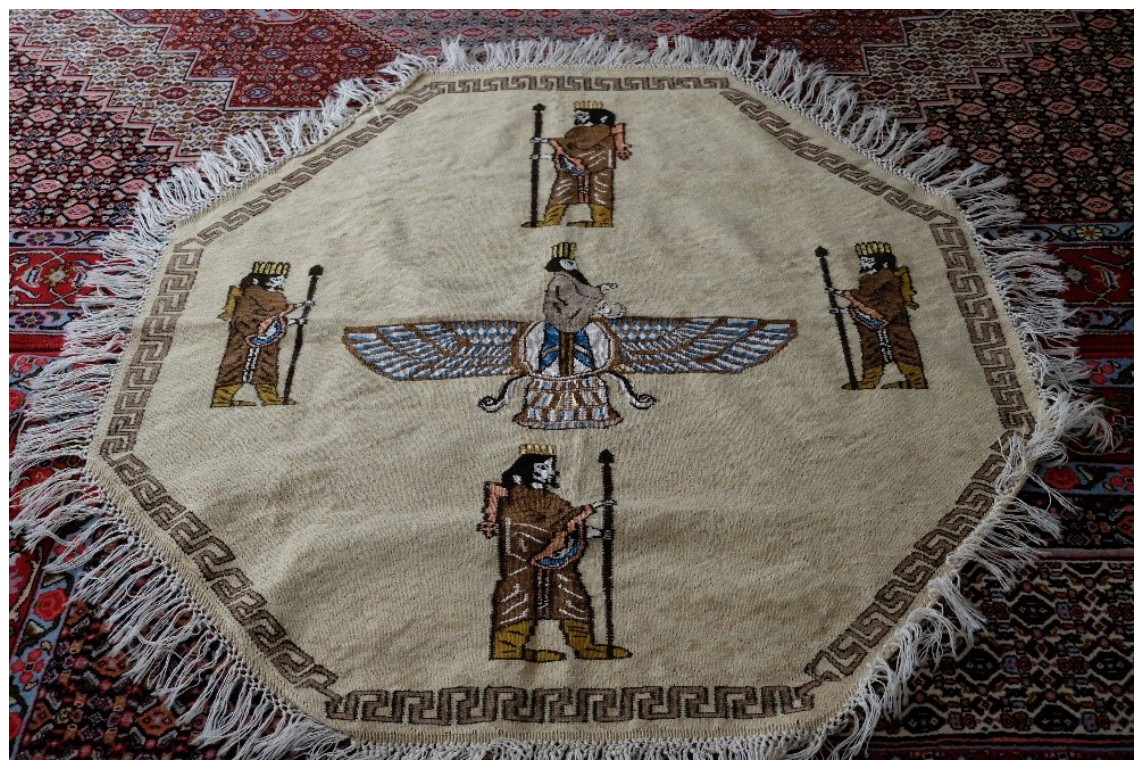

Figure 10. A hexagonal-shaped senneh gelim made by Fatemeh, a skilful independent artisan from Sanandaj. The design elements, the Achaemenid guards/figures and Faravahar at the centre, are unusual in a senneh pattern, demonstrating her artistic and marketing ambi 


\section{The geography of senneh gelim: Sanandaj and its periphery}

Senne gelim evidently has a long history in Sanandaj and is commonly said to have been the crucial centre of the craft's production. Several older quarters of the city, at least since the late-nineteenth century, were known for their production and for senneh artisans. ${ }^{20}$ Women in the Qatar-Chian neighbourhood, for instance, were particularly renowned carpet weavers in the past because the adult males in this neighbourhood were commonly muleteers in charge of transportation (the name of the neighbourhood refers to "muleteers"). ${ }^{21}$ Often, men had to leave their families behind for long periods to transport products between regions and towns by mule. In the absence of their husbands, the women of these households spent their spare time weaving senneh gelims and pile rugs for the market. On the other hand, many remote villages across Kurdistan province in the districts of Dehgolan, Kamyaran, and Marivan are currently known for their senneh gelim production. ${ }^{22}$

The present geographical dispersion of weaving centres raises questions about whether Sanandaj was indeed the historical birthplace of senneh gelim as generally agreed upon, and if so, when and how this geographical spread of production centres into remote provinces occurred. Whatever the case, comparing modern rural and urban looms' products demonstrates differences in construction, materials, design patterns, and colour palettes (compare Figure 11, Figure 12)

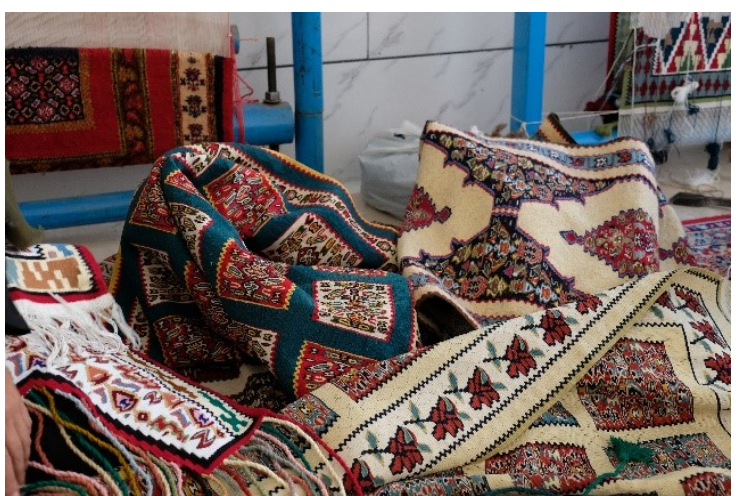

Figure 11. Senneh gelim products of dependent urban looms

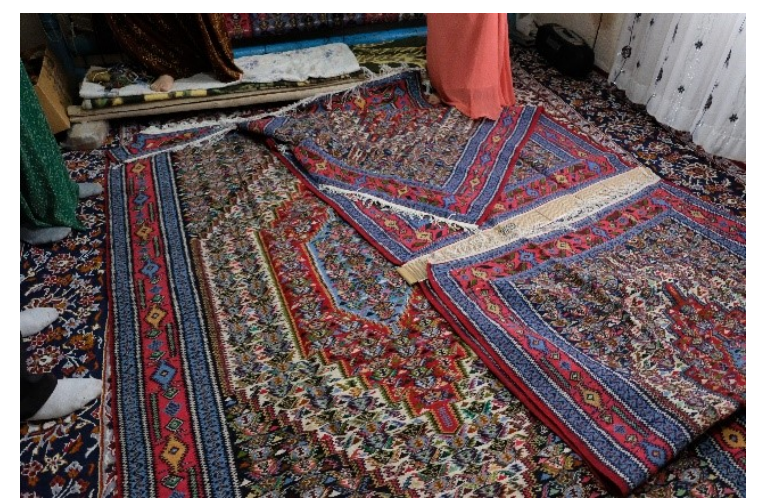

Figure 12. Senneh gelim products of dependent rural looms 
Senneh gelims made by rural (independent) artisans have a coarser construction due to the widespread use among village artisans of lower-grade wool yarns (industrially-processed, dyed with synthethic dyes) known as khaame-ye-mashini or khaame-ye-san'ati. ${ }^{23}$ This choice seems to have been based on the lower cost compared to finer and higher quality wool ranges referred to as kork (still industrially processed, dyed with natural dyestuffs) used commonly among urban artisans. Village senneh gelims also show less diversity in patterns and design elements. Rural weavers tend to simplify the highly complex and busy design motifs of the traditional patterns so that the intricate, curvilinear motifs of traditional senneh patterns, such as the Herati design motifs, are simplified into more geometric, abstract versions. The same contrast can be observed in the selection of colours and colour proportions in village products versus urban weaves (Figure 13, Figure 14, Figure 15). The prominent colours in village gelims are often blue, red, and white, compared with a broader range and subtler colours in urban senneh gelims that, according to producers, demonstrate a more careful choice of colours designed to appeal to cosmopolitan consumers. But perhaps most notably, senneh gelims - despite being produced by many rural women as will soon be seen-do not appear today in the village artisans' households, suggesting that senneh gelim production may not have been part of the indigenous traditions in rural Kurdistan. Recognizing that a significant characteristic of any indigenous craft in its originating context is that it is made for functional, decorative, and/or ritual purposes, it is clear that Kurdish women in rural areas do not make senneh gelim for their households for these uses, nor do they include it in their daughters' trousseau or present it as a gift to newlywed family members and relatives. For them, senneh gelims exist only to sell, whereas in urban independent artisans' homes, regardless of the household's economic circumstances, senneh gelims are often used as household items - for instance, as a paa-dari or doormat, a roo-poshti or cushion cover, or a floor cover. It is also not uncommon among independent urban artisans to put aside the best of their works to be included in an unmarried daughter's trousseau. Finally, most rural artisans noted that their mothers and grandmothers made pile carpets or other indigenous textiles, such as mowj, ${ }^{24}$ barr, ${ }^{25}$ and jajim, ${ }^{26}$ and only a few younger artisans said that earlier female generations 
in their families were senneh weavers.
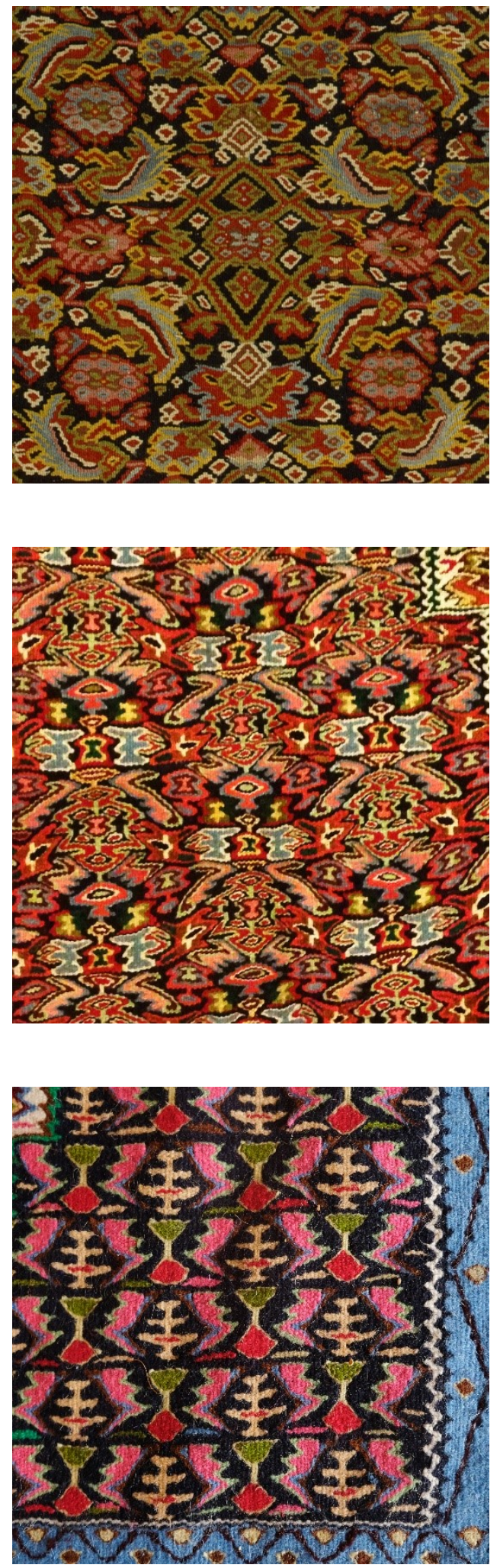

Figure 13. Details of the Herati design of an old senneh gelim which dates from the late-nineteenth/early twentieth century. Courtesy of the George Washington University Textile Museum, bequest of Arthur D. Jenkins (object number:1989.10.48).

Figure 14. Details of the Herati design, produced in an independent urban workshop, woven by Shahnaz from Sanandaj, Kurdistan. Photographed by the author, Sanandaj, December 2018.

Figure 15. Details of the Herati design, a product of an independent rural workshop, show a simplified variation of the design, woven by Ameneh from the village of Kakuye-Sofla, Kurdistan. Photographed by the author, April. 2020 
However, it appears that the spread of senneh weaving in remote regions of Kurdistan was mainly instigated by some public organizations during the 1980s. My field inquiries revealed that at least two public organizations provided weaving training programs to promote commercial carpet production among women to eliminate rural poverty. ${ }^{27}$ One of these programs run by the regional branch of the Traditional Handicraft Organization began during the Iran-Iraq war (1980-1988) and specifically targeted several remote and impoverished Kurdish villages near the Iran-Iraq borders, where populations were caught up, on the one hand, in the Iran-Iraq war and in the fights between Kurdish insurgents and the Iranian government on the other. Funded by the government's budget allocated to the reconstruction of war-affected areas, the plan continued in the targeted villages for several years after the war ended in 1988. Many questions about these projects (and other government-based and otherwise-funded weaving projects in the second half of the twentieth century) remain unanswered. Nonetheless, they certainly had a crucial role in determining the craft's development in recent history and its continuation up to the present. Many rural villages, such as Buridar, with no history of senneh gelim tradition, have become active production centres for several decades now, and some village women have been able to use weaving as a means of independent income. Even a regional weaving style of Herati design has emerged. Haj-Yahya, a gelim seller in the Sanandaj bazaar, said he could identify gelims made by Buridar weavers' hands whenever he saw one. ${ }^{28}$ Clearly, senneh gelims —as a source of economic return - today have value in the eyes of rural Kurdish women as they have long had for urban women. However, as discussed, the examination of the various sites and manner of their production reveals many other differences and similarities between them in terms of their physical and aesthetic features. Now, I turn to the organization of production in various urban and rural settings by focusing on the role of women weavers and where they are situated socially, culturally, and economically. 


\section{Senneh gelim production settings in contemporary Kurdistan}

This research has established that senneh gelim workshops across urban and rural regions in contemporary Kurdistan can be placed in three distinct categories according to: 1) the physical and social geography of the production settings and 2) whether the means of production are owned by individual artisans or by private investors/loom owners. The first category consists of independent urban artisans, women from the lower middle to lower urban classes concentrated in the inner-city areas of Sanandaj. They have the means of production - a loom, weaving equipment, and adequate capital to purchase the next project's required materials. By contrast, women in the second category work as contracted weavers or wage laborers for private employers/loom owners in dependent rural and urban workshops and do not have the financial means to set up their own work. Dependent weavers are concentrated in most impoverished urban areas in the city's outskirts (e.g., Naysar and Forje) and in several rural villages, mostly in the city's periphery (e.g., Haji-Abad and Baba-riz). The third category consists of independent rural workshops scattered across some remote Kurdish villages across the province. As in independent urban workshops, independent women weavers have weaving skills, economic means, and equipment required for commercial weavings. Still, both urban and rural women - and those working independently or for others - experience similar gendered, class-based, and ethnic forms of exploitation and oppression, a topic I now turn to.

Contemporary women artisans' roles in the production and trade of their craft are formed in accord with the long-lasting patriarchal gendered division of labor and modern capitalist production relations in Iranian Kurdistan. As in the traditional senneh production system, contemporary women weavers in all groups are at the center of the production as senneh makers, responsible for the actual labour. However, most women are not directly engaged in commercial transactions of their craft in the carpet bazaar unless accompanied by a male companion. Customarily, the family's male members are responsible for managing the household's affairs with the outside world. Fathers, husbands, sons, or a close male relative (in the case of independent artisans) and workshop managers (in the case of dependent artisans) serve as intermediaries. They arrange for 
women's work, provide the loom, purchase yarns, and finally deal with the market to price and commodify the women's labours' as end products. Not surprisingly, the contemporary carpet market, the center of the trade of raw materials and finished products, is strictly managed and controlled by men and dominated by the ideology and practices of a highly conservative culture. It remains a "no-go zone" for women to engage in controlling and managing their finished products' trade. Consequently, the distribution of financial gain is disproportionate, as craftswomen, although at the center of the production, are situated at the bottom of the hierarchy of beneficiaries and receive the lowest share of the financial gains. Petty dealers, shopkeepers, capitalist loom owners/entrepreneurs (mostly local), and intermediary and big carpet merchants (mostly non-locals), all predominantly men, are situated above the weavers' position and reap the benefits accordingly.

Moreover, senneh gelim is predominantly the commercial craft of Kurdish women from the lower socio-economic strata of urban and rural populations with no access to official and regulated job markets outside the domestic sphere. This is manifested most obviously within dependent urban workshops concentrated in marginalized urban areas in Kurdistan, such as Naysar, where uprooted rural immigrants and the urban poor and underclasses make up the majority of the population. Kurdish regions are among the most socio-economically underdeveloped provinces in Iran. ${ }^{29}$ At the beginning of the twentieth century, the Kurdish societies in the country's periphery that had lived for centuries as self-governing principalities, became politically, socially, and economically integrated into and dependent on the central state. ${ }^{30}$ Reluctant to adopt an inclusive and pluralistic approach, the secular Pahlavi regime neglected various ethnic and religious minority groups, including the Kurds, following its Persian-centric public policies. Today, under the Islamic Republic's Shi'i supremacist discourse, the Kurds, the majority of whom are Sunni, are subjected to state-based ethnic and religious discriminatory policies believed by Kurds to be deliberate acts intended to weaken their independence and nationalist movements. Kurdish regions, which have experienced a low standard of living for decades, today remain 
marked by ongoing poverty and high rates of unemployment and illiteracy especially among the female populations.

One of the major consequences of rural underdevelopment is the influx of rural immigrants from impoverished Kurdish villages to Kurdish urban regions since the 1960s. Poverty is also widespread among the newly urbanized immigrant households due to the unemployment or underemployment of male heads of families. Women of these households often find themselves in a desperate search for income while traditional cultural values, such as strictly demarcated feminine/masculine roles and codes of behaviour and gender segregation, act as a double-edged sword against them. Not only do they face resistance from the male members of their families to their working outside the home, but also these values act as internalized impediments to seeking non-domestic jobs. On the other hand, factors such as limited literacy, lack of official (Farsi) language skills, and lack of skills and education for official jobs bar women from entering the already weak job market in Sanandaj. Under these circumstances, weaving gelim and rug as a contracted labourer provides a plausible work option. These jobs offer a sex-segregated and culturally "appropriate" form of gendered work that requires no capital, can be performed in the private space of the home or communal carpet workshops set up in large numbers in the city's marginalized neighborhoods by private loom owners, and are thus unlikely to face resistance from male family members. However, unlike formal jobs, these occupations are unregulated, meaning the wage rates are extremely low (much lower than the legal minimum wage rate set by the Iranian Employment and Labour law for unskilled workers). Women report that the timing of payment has been irregular and frequently delayed, and workers have lacked any benefits (social, unemployment, and health insurance). In effect, with inadequate public policies to protect contracted weavers' rights and a lack of resources to oversee their operations, dependent workshops run by profit-oriented entrepreneurs have become potential sites for exploiting contracted female weavers.

Over recent years, however, the senneh producers have come under extreme pressure due to a sharp decline in domestic and export markets. Fatemeh, a senior independent urban carpet 
artisan from Sanandaj and a prolific weaver for over five decades, recalled a time when weaving sojaee could be a more viable means of income for urban women weavers. Encouraged by her mother, she learned carpet weaving at the age of seven from a woman in the neighborhood, a divorcee who supported her family by carpet weaving. Despite growing up in a lower-middle-class household, like the majority of girls in Kurdistan at the time, she did not attend school because her father was against girls' education. But, she was encouraged to make pile carpets for the market, starting from the age of eight. She proudly recounted how her trousseau was entirely paid with the money she had earned from weaving.

In recent years, due to the international sanctions against Iran beginning in 2018 that have targeted the country's economy, including the carpet industry, making senneh has become a progressively less viable means of livelihood for women like Fatemeh. It becomes extremely difficult for local weavers to produce when market demands are falling, the cost of raw materials continues to grow due to rising inflation, and their earnings remain extremely low. For the production to stay profitable, today traders and loom owners, either in their struggle for survival or by taking advantage of the availability of cheap labor and their vulnerable position, clearly exploit the weavers. I met independent senneh artisans in Sanandaj's urban areas, the historical birthplace of senneh gelim, like Fatemeh, who find it less and less feasible to produce senneh for a livelihood. Weavers with other sources of family income have stopped altogether. However, the production persists in marginalized urban areas in the city's peripheries, mainly within the dependent workshops. Here, weavers have few other livelihood options and have acceded to worsening working conditions and wage rates, and thus continue to produce.

Despite its potential, senneh gelim production in any settings is not a means of empowering women weavers and hardly has led to any significant, constructive changes in their financial and social wellbeing, and old patterns of early marriage and under-education of young girls in weavers' families in both urban and village milieus persists. In the fifteen households I visited where there were adolescent girls, four girls around the age of sixteen or younger had already dropped out of school and were married or were to be married soon, just like their mothers and 
other women of past generations in their families and neighbourhoods had been before them. My statistical population presented here is small, but the figure (twenty-six percent) is not far removed from the national statistics for early marriage in Iran, estimated to be around twenty percent. ${ }^{31}$ Without a doubt, early marriage, which in Iran is sanctioned by custom and religious laws and institutionalized in the country's legal system, deprives women of their right to education and ensures that they will remain economically dependent for the rest of their lives. ${ }^{32}$ Unequivocally, weaving carpet under systematically exploitative conditions as such only perpetuates the cycle of poverty and socio-economic, gendered, cultural discrimination Kurdish women carpet weavers experience.

\section{Conclusion}

This research presents a sketch of the senneh gelim weaving tradition and its historical and current trajectories. Rooted in the rich ancient textile traditions of these regions' tribal and village populations, senneh gelim was developed as an urban textile in the late eighteenth century under local Kurdish nobilities' patronage, becoming the finest flatweave carpet ever to have come out of Kurdish looms. In the face of modern capitalist carpet production beginning in the second half of the nineteenth century, senneh gelim, unlike many pre-modern Kurdish handcrafts, neither perished nor were substantially transformed. However, its continuation over the second half of the twentieth century was largely instigated by some public institutions and their

protective measures that attempted to revitalize traditional craft by reinvigorating it as an economic activity. It seems that the transformation of senneh gelim's social function and meanings from a signifier of status and wealth in the past to an ethnic commodity in modern times was instrumental in its survival.

Yet it appears that the contemporary senneh gelim has taken a different path from its historical predecessor. Over the last several decades, senneh gelim has entered a new developmental phase, as Sanandaj has lost its centrality in the production of senneh, and senneh workshops have spread across the Kurdistan province. This has inevitably brought many changes in all aspects of 
the craft's construction, materials, aesthetics, and meanings. Village senneh gelim production in independent workshops has gradually incorporated materials and stylistic traits reflective of new rural production contexts. Historical senneh pieces have long been praised for the masterful execution of slit-tapestry technique and sophisticated designs and highly distinguished from the allegedly inferior village and nomadic flatweaves in the region. A reverse transition seems to have occurred, as the senneh gelim (within the independent rural setting) has returned to its humble rural origins, marking the closing of a circle.

Still, the future of this remarkable textile heritage is uncertain. Like most traditional handicraft industries, senneh gelim has been struggling in the internal and export market due to a combination of many internal and external factors, such as changing patterns of lifestyle, taste, and consumption, wide availability of cheaper imported goods, the global economy, and the region's geopolitics. However, the most inhibiting factor is inherent within the system-the vertically integrated social and economic relations of women weavers to the rest of the actors, all of whom are prddominantly male. Coupled with other factors, this has limited the craft's potential to provide the weavers I met with a socially and economically sustainable livelihood, creating a systematic means of exploiting the most marginalized population groups. Indeed, the senneh gelim tradition in each of its production settings reflects contemporary Kurdish women weavers' experience of oppression and exploitation resulting from their social identity. This highlights the complex relationship between long-lasting patriarchy and economic materialism, indicating that, as in the past, the operational dynamics of the present-day Iranian handmade carpet production in general, and senneh gelim production, in particular, are organized based on inequality of gender, class, and ethnicity.

It was clear to me throughout my research that the solution was obvious but unlikely to appear: facilitating the establishment and empowerment of artisans' communities, where independent individual weavers can form associations to meet their economic, social, and cultural needs and aspirations through jointly owned, organized, and controlled enterprises. This could 
lead to sustainable livelihoods and, consequently, to the development, preservation, and prospering of a craft of enormous cultural and historical value both to the Kurds themselves, to the women who weave it, and to those who treasure it.

\section{Acknowledgment}

I would like to acknowledge the late Prof. Vicki Cassman, my first doctoral supervisor, and my advisors Patricia Sloane-White, Margaret Stetz, Rudolph Matthee, and Sumru Belger Krody for sharing their invaluable knowledge and expertise with me and guiding me throughout my research. Also, I would like to sincerely thank Patricia Sloane-White and Margaret D. Stetz, for editing the early and final versions of this manuscript. 


\section{References}

${ }^{1}$ P. Tanavoli, Persian Flatweaves: A Survey of Flatwoven Floor Covers and Hangings and Royal Masnads (Woodbridge: Antique Collectors' Club, 2002).

2 Ibid.

3 See: A. Landreau, 'Kurdish Kilim Weaving in the Van-Hakkari District of Eastern Turkey,' Textile Museum journal, Volume: 3, 1973, Pages: 26-42; C. M. Cootner, Flat-Woven Textiles (Washington, D.C.: Textile Museum, 1981); R. Biggs, Robert, Discoveries from Kurdish Looms (Evanston, Ill. : Mary and Leigh Block Gallery, Northwestern University,1983); W. Eagleton, An Introduction to Kurdish Rugs and Other Weavings (American ed. New York: Interlink Books, 1988); A. Akasheh, 'Woven Skies, Woven Lands: Kurdish Textiles as an Expression of Social Structure.' in Kurdish Times Vol.1, issue.1, 1986), pp 21-23, http://search.proquest.com/docview/216671858 (accessed June 21, 2021); W. Stanzer and F. A. Besim, Kordi: Leben, Knüpfen, Weben Der Kurden Khorasans = Lives, Rugs, Flatweaves of the Kurds in Khorasan (Wien: Adil Besim OHG im Eigenverlag, 1993); Tanavoli, Persian Flatweaves; J. D. Burns, Antique Rugs of Kurdistan: A Historical Legacy of Woven Art (London, 2002).

${ }^{4}$ C. L. Costin, 'Introduction: Craft and Social Identity,' p.3. Costin, R. P. Wright, P. Wattenmaker, E. M. Brumfiel, Craft and Social Identity, ed. C. L. Constin, R. P. Wright (Arlington, Va.: American Anthropological Association 94th: 1995: Washington, D. C. 1998), https://delcat.on.worldcat.org/oclc/40311568 (accessed June 19. 2021).

${ }^{5}$ The fieldwork was carrier out from July 2018 to September 2019 consisted of twelve short-to-mediumlength trips to Sanandaj and several towns and villages within the province. Open-ended qualitative primary data was collected using semi-structured and unstructured/casual interviews, conversations, observations, and audiovisual recordings. Seventy-eight individuals participated in this research, among whom fourty-nine were senneh gelim weavers, pile carpet weavers, and former weavers of other traditional textile types.

${ }^{6}$ See: Tanavoli, Persian Flatweaves; Burns, Antique Rugs of Kurdistan; C. Bier, Woven from the Soul, Spun from the Heart: Textile Arts of Safavid and Qajar Iran, Sixteenth-Nineteenth Centuries, (Washington, D.C.: Textile Museum, 1987); J. Housego, Tribal Rugs: An Introduction to the Weaving of the Tribes of Iran (London: Scorpion Publications, 1991).

${ }^{7}$ Some institutions with significant senneh gelim collections include the George Washington University Textile Museum (US), the Metropolitan Museum of Art (US), the Victoria \& Albert Museum (UK), and the Carpet Museum of Iran.

${ }^{8}$ Tanavoli, Persian Flatweaves, pp. 42-46.

${ }^{9}$ Ibid.

${ }^{10}$ See: C. Edwards, The Persian Carpet: A Survey of Carpet-Weaving Industry in Persia, 1953); Bier, Woven from the Soul, Spun from the Heart; Burns, Antique Rugs of Kurdistan; Tanavoli, Persian Flatweaves; S. Ardalan, Khandan-e Kurd-e Ardalan dar Talaqū-i Imperatūrī'ha-ye Iran va Othmanī (Tehran: Nashr-e Tarīkh-e Iran, 2008).

${ }^{11}$ See: C. C. Jackson, 'Persian Carpets and the South Kensington Museum: Design, Scholarship and Collecting in Late Nineteenth-Century Britain,' Journal of Design History 30, no. 3 (2017), pp.265-281. doi:10.1093/jdh/epw029. https://delcat.on.worldcat.org/oclc/7169213270.; A. Ittig, 'CARPETS xi. Qajar Period,' Encyclopoedia Iranica, IV/8, available online at https://iranicaonline.org/articles/carpets-xi (accessed June 07. 2021); L. M. Helfgott, Ties that Bind: A Social History of the Iranian Carpet (Washington: Smithsonian Institution Press, 1994).

12 Helfgott, Ties that Bind., p.222

${ }^{13}$ For more details regarding the introduction of the capitalist economy to Iran in the late-nineteenth century and its consequences for the pre-existing market systems see: J. Foran, Fragile Resistance: Social Transformation in Iran from 1500 to the Revolution (Boulder: Westview Press, 1993); Helfgott, Ties that Bind.

14 Tanavoli, Persian Flatweaves, pp.39-40.

${ }^{15}$ My attempts to access official documents relating to the Iranian government's plans and programs in regard to the revitalization of heritage handicrafts during this period were unsuccessful. Further investigation into government archives and official records would be most beneficial to shed light on the craft's recent history.

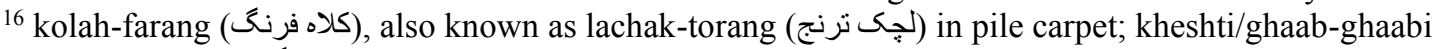

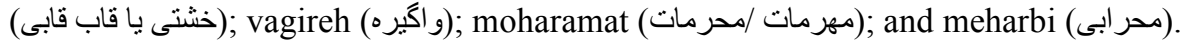




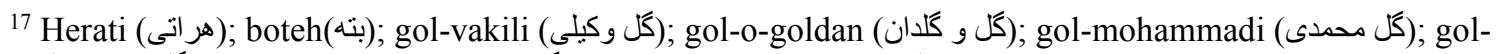

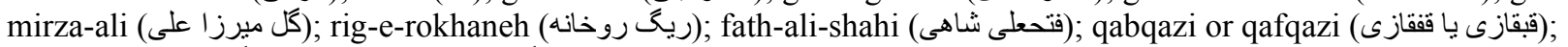

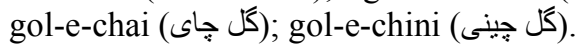

18 See: A. Levi, 'Renewal and Innovation: Iconographic Influences on Kurdish Carpet Designs,' Hali, Issue 70, Vol. 15, no.4 (1993), pp.85-94; Cootner, Flat-Woven Textiles; Tanavoli, Persian Flatweaves.

${ }^{19}$ Eagleton, An Introduction to Kurdish Rugs and Other Weavings.

${ }^{20}$ These neighborhoods are Qatar-Chian, Agheh-Zaman, Qala-Cholan, Tazeh-Abad, Chaar-Bagh, PeerMohammad-Mahale, and Mahale-Farah.

21 S. Mazumdar \& S. Mazumdar, 'Rethinking Public and Private Space: Religion and Women in Muslim Society,' in Journal of Architectural and Planning Research, Vol. 18, No. 4 (Winter, 2001), pp.302-324

${ }^{22}$ Some of villages with active senneh weavers are Kheir-Abād, Sreinjyāneh, Moochesh, Bāshmagh, Godmirān-Olia and Godmirān-Sofla, Mard-Abād, Nabi-Abād, Mobārak-Abād, Kakuye-Sofla, Kakuye-Olia, and Buridar.

${ }^{23}$ Cheaper varieties, refered to as khaame-e-mashini or khaame-e-san'ati, meaning machine-made and industrial wool respectively, include wool called pashm-e-dabaaqi which is sourced from slaughterhouse and obtained from the sheep's dead skin using chemicals, instead of shearing. As a result of chemical processes, the wool yarn is rough.

${ }^{24}$ Mowj is a type of fabric made on a horizontal pit-treadle loom in Iranian Kurdistan. The pieces are long and narrow, with a width measuring between $60 \mathrm{~cm}$ to $80 \mathrm{~cm}$. Usually, a larger square piece is made by sewing the narrow pieces along the length. Mowj is made primarily with wool yarns and used as a bed wrapping, blanket, or throw in traditional village households.

${ }^{25}$ Barr in Iraqi and Iranian Kurdistan, is used to refer to floor coverings or carpets made with various flat weaving methods ranging from slit-tapestry to simple or compound weft-wrapping techniques. In Iranian Kurdistan, the word barr still is used by senior or former village artisans to refer to the rough and heavy village and tribal flatweaves that are no longer actively produced in these regions. When the word "gelim" is used singularly in Iranian Kurdistan, it refers to the coarse and utilitarian village or tribal flatwoven plain-weave carpets. By contrast, the terms "senneh gelim" or "bijar gelim" are used exclusively to refer to the refined tapestry-woven flatweaves produced in the cities of Sanandaj and Bijar.

${ }^{26}$ Jajim is a traditional warp-faced flatweave textile, narrow and long, made on a horizontal treadle loom known as a dare-e-jula, using a warp-faced technique.

27 These organizations are the Jahad Construction Organization (JCO) and the regional branch of the Traditional Handicraft Organization (THO). The THO is the predecessor organization of the Administration of Traditional Arts and Handicrafts (ATAH). It formerly oversaw the administration of traditional handicrafts in Iran. Currently, the ATAH is the government body responsible for the promotion and preservation of traditional handicrafts in Iran.

${ }^{28}$ Haj-Yahya, Interview by the author, Sanandaj bazaar, Kurdistan, January 2019.

${ }^{29}$ See: E. Abdoh-Tabrizi and A. Shahi, 'The Shi'i State and the Socioeconomic Challenges of the Sunni Communities in Iran, in Sites of Pluralism, (Oxford: Oxford University Press, 2019), https://doi.org/10.1093/oso/9780190052713.003.0005, (accessed June 07, 2021); F. Farideh Koohi-Kamali, The Political Development of the Kurds in Iran: Pastoral Nationalism (New York: Palgrave Macmillan, 2003).

${ }^{30}$ See: A. Vali, Kurds and the State in Iran: The Making of Kurdish Identity, (London; New York: I.B. Tauris, 2011); M. V. Bruinessen, Agha, Shaikh, and State: The Social and Political Structures of Kurdistan, (London: Zed Books, 1992); A. Ghassemlou, Kurdistan and the Kurds, (Prague: Czechoslovak Acad. of Sciences u.a., 1965).

31 According to official statistics, thirty-four percent of girls married (nationwide) in 2017 were nineteen or younger, while three percent were age ten or younger (217), 5.8 percent were between ten and fourteen (35,333), and twenty-eight percent were between fifteen and nineteen $(17,0926)$. Unfortunately, due to the method of age classification of the statistics, it is difficult to obtain an accurate estimate of girls' marriages under eighteen, which is the international minimum legal age of marriage, for comparative analyses. However, some sources have stated that the real number is around twenty percent or higher. See: Statistical Center of Iran, Statistical Yearbook of 2017 (Tehran: Office of the Head of Public Relations and International Cooperation, Statistical Center of Iran, 2018), pp. 195-196, https://irandataportal.syr.edu/wp-content/uploads/Statistical-Yearbook-2016-2017-1395-\%E2\%80\%93-Persian-.pdf (last viewed September 02, 2021); Factnameh, آمار كودكهمرى در ايران جقدر است؟', Factnameh, February 08, 2018, https://factnameh.com/fact-checks/2019-02-08-child-marriage.html (accessed July 07. 2021). 
${ }^{32}$ The legal minimum age of marriage in Iran is currently thirteen for girls and fifteen for boys (as of July, 2021). There is a legal loophole under Article 1041 of the Iranian civil code that states girls younger than thirteen require the permission of their male guardian and the courts prior to any marriage taking place. 